\title{
Author Correction: Caenorhabditis elegans is a useful model for anthelmintic discovery
}

Andrew R. Burns, Genna M. Luciani, Gabriel Musso, Rachel Bagg, May Yeo, Yuqian Zhang, Luckshi Rajendran, John Glavin, Robert Hunter, Elizabeth Redman, Susan Stasiuk, Michael Schertzberg, G. Angus McQuibban, Conor R. Caffrey, Sean R. Cutler, Mike Tyers, Guri Giaever, Corey Nislow, Andy G. Fraser, Calum A. MacRae, John Gilleard \& Peter J. Roy

Correction to: Nature Communications https:/doi.org/10.1038/ncomms8485, published online 25 June 2015.

The original version of this Article contained an error in the spelling of the author Luckshi Rajendran, which was incorrectly given as Luckshika Rajendran. This has not been corrected in the PDF and HTML versions of the Article.

Published online: 24 July 2020

(c) Open Access This article is licensed under a Creative Commons Attribution 4.0 International License, which permits use, sharing, adaptation, distribution and reproduction in any medium or format, as long as you give appropriate credit to the original author(s) and the source, provide a link to the Creative Commons license, and indicate if changes were made. The images or other third party material in this article are included in the article's Creative Commons license, unless indicated otherwise in a credit line to the material. If material is not included in the article's Creative Commons license and your intended use is not permitted by statutory regulation or exceeds the permitted use, you will need to obtain permission directly from the copyright holder. To view a copy of this license, visit http://creativecommons.org/licenses/by/4.0/.

(C) The Author(s) 2020 